\title{
Modulation of Polymorphonuclear Leukocyte Microbicidal Activity and Oxidative Metabolism by Fibrinogen Degradation Products D and E
}

\author{
James W. Kazura, Jay D. Wenger, Robert A. Salata, Andre Z. Budzynski, and George H. Goldsmith \\ Divisions of Geographic Medicine and Hematology/Oncology, Department of Medicine, University Hospitals of Cleveland, and \\ Case Western Reserve University, Cleveland, Ohio 44106; and Department of Biochemistry, \\ Temple University School of Medicine, Philadelphia, Pennsylvania 19140
}

\begin{abstract}
Fibrinogen degradation products (FDP) D and E are typically present in blood of patients with disseminated intravascular coagulation and related conditions in which granulocyte (PMN) defense against bacterial infection may be compromised. This study was intended to determine whether FDP modify PMN functions critical to their bactericidal activity. Incubation of human PMN and Escherichia coli with 50-100 $\mu \mathrm{g} / \mathrm{ml}$ FDP did not affect phagocytosis, but reduced by $>90 \%$ the cells' ability to inhibit bacterial colony growth compared with control PMN incubated with albumin or fibrinogen. FDP $(10-100 \mu \mathrm{g} / \mathrm{ml})$ inhibited $P M N O_{2}^{-}$release and chemotaxis stimulated by FMLP by $17-50 \%(P<0.005)$ and $41 \%(P$ $<0.01$ ), respectively. Fragment $E_{3}$, and not fragment $D_{1}$, was primarily responsible for inhibition of FMLP-induced PMN $\mathrm{O}_{2}^{-}$release. Phorbol myristate acetate $(10 \mathrm{ng} / \mathrm{ml}), 1-0 l e o y l-2-$ acetylglycerol $\left(10^{-6} \mathrm{M}\right), \mathrm{AA}\left(4.2 \times 10^{-5} \mathrm{M}\right)$, and zymosan-activated serum-stimulated $\mathrm{PMN}_{2}^{-}$release were also decreased 37-63\% by FDP compared with control protein. There are at least two mechanisms by which FDP may impair PMN responses. With respect to FMLP, FDP $(16-100 \mu \mathrm{g} / \mathrm{ml})$ inhibited specific binding to the cell surface over a ligand concentration range of 1.4-85 $\mathrm{nM}\left[{ }^{3} \mathrm{H}\right] \mathrm{FMLP}$. In contrast, FDP did not effect the extent of phorbol ester binding to PMN but blocked activation of protein kinase $C$. These data suggest that elevated plasma FDP inhibit several PMN functions critical to the bactericidal role of these inflammatory cells.
\end{abstract}

\section{Introduction}

Fibrinogen $(\mathrm{Fbg})^{1}$, fibrin, and degradation products of these plasma proteins (FDP) have important effects on several

This work was presented in part in abstract form (1984. Clin. Res. 32:311).

Address reprint requests to Dr. James W. Kazura, Department of Medicine, Division of Geographic Medicine, University Hospitals of Cleveland, Cleveland, OH 44106.

Received for publication 22 February 1988 and in revised form 15 February 1989.

1. Abbreviations used in this paper: DIC, disseminated intravascular coagulation; Fbg, fibrinogen; FDP, fibrinogen degradation products; KGEP, homogenizing buffer consisting of $139 \mathrm{mM}$ potassium glutamate, $20 \mathrm{mM}$ Pipes, pH 6.6, $5 \mathrm{mM}$ EGTA, $5 \mathrm{mg} / \mathrm{ml} \mathrm{BSA}$, and 50 $\mu \mathrm{g} / \mathrm{ml}$ leupeptin; OAG,' 1-oleoyl-2-acetylglycerol; PDBU, phorbol12,13-dibutyrate; PKC, protein kinase C; PMA, phorbol myristate acetate; ZAS, zymosan activated serum.

J. Clin. Invest.

(c) The American Society for Clinical Investigation, Inc.

0021-9738/89/06/1916/09 \$2.00

Volume 83, June 1989, 1916-1924 aspects of inflammation. Perhaps most thoroughly studied is their role in platelet activation. In many circumstances, occupancy of platelet Fbg receptors with intact Fbg precedes platelet secretion and aggregation which support normal hemostasis (1-3). Elevation in plasma FDP, such as in disseminated intravascular coagulation (DIC) or adult respiratory distress syndrome, may inhibit the interaction between platelet Fbg receptors and Fbg and contribute directly to platelet dysfunction and bleeding diathesis (4-6). Several studies suggest that FDP may also have deleterious effects on other cells involved in acute inflammation. Fragment D, a $\sim 100$-kD plasmin-generated FDP, induces cytoskeletal alterations and eventual retraction of venous endothelial cells in vitro $(7,8)$. Fragment $E$, $\mathrm{a} \sim 50-\mathrm{kD}$ FDP, competes with Fbg for fibroblast Fbg binding sites and inhibits directed migration of these cells in a Fbg concentration gradient $(9,10)$. Low molecular weight Fbg degradation products have been shown to decrease lymphocyte blastogenesis $(11,12)$. With regard to PMN, various low molecular weight $(<20 \mathrm{kD})$ polypeptides derived from $\mathrm{Fbg}$ have been found to induce chemotaxis (13). Possible PMN chemotactic activity of fragment $\mathrm{D}$ has also been reported $(14,15)$. Human fibrinopeptide $B$ has chemotactic activity for PMN in potency equivalent to that of C5a, leukotriene $\mathrm{B}_{\mathbf{4}}$, and FMLP (16). These observations suggest that increases in the plasma concentration of various Fbg fragments modify the inflammatory response by virtue of their effects on multiple cellular components of blood. Because clinical situations in which DIC occurs are commonly associated with severe bacterial infections and neutropenia (17), we initiated studies to define more clearly the effects of FDP and related activated coagulant proteins on PMN functions related to host defense against bacteria.

\section{Methods}

Preparation of Fbg and FDP. Lyophilized human Fbg (Imco, Stockholm, Sweden) was dissolved in distilled water and dialyzed against $0.01 \mathrm{M} \mathrm{PBS}, \mathrm{pH} 7$, for $18 \mathrm{~h}$ at $4^{\circ} \mathrm{C}$. Dialyzed Fbg was stored at $-20^{\circ} \mathrm{C}$ until use. To prepare FDP, Fbg was incubated with plasmin $(0.0025$ $\mathrm{mg} / \mathrm{ml}$ final concentration) at $37^{\circ} \mathrm{C}$ for $1-3 \mathrm{~h}$. Proteolysis was stopped by addition of tosyllysyl chloromethyl ketone and phenylalanylarginyl chloromethyl ketone (Sigma Chemical Co., St. Louis, MO), followed by dialysis at $4^{\circ} \mathrm{C}$ against PBS and sodium azide (18). Mixed $D$ and $E$ fragments were separated from lower molecular weight degradation products by passage of the preparations over a Sephadex G150 column $(80 \times 2.5 \mathrm{~cm})$. FDP was dialyzed against PBS before use. The presence of $D$ and $E$ fragments was verified by SDS-PAGE run under nonreducing conditions. These preparations displayed characteristic bands of 80-100 (fragments $D_{1,2,3}$ ) and $50 \mathrm{kD}$ (fragment $E$ ), and minor components between 50 and $100 \mathrm{kD}$ after staining with Coomassie blue (Fig. 1) (18-20). In studies directed at defining the species of FDP that affect FMLP-stimulated PMN $O_{2}^{-}$release, fragments $D_{1}$ and $E_{3}$ were separated and purified from plasmin-digested Fbg by Pevikon block 


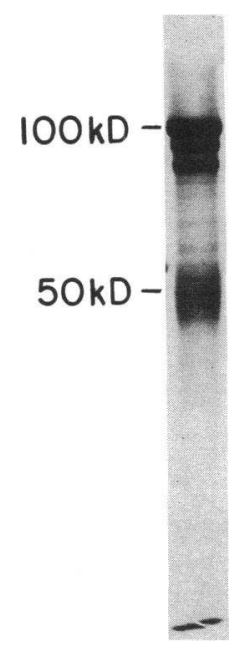

Figure 1. SDS-PAGE of FDP. $20 \mu \mathrm{g}$ of FDP were run on a $10 \%$ SDS-PAGE and stained with Coomassie blue.

electrophoresis as described (21). The homogeneity and lack of crosscontamination between preparations of fragments $D_{1}$ and $E_{3}$ were confirmed by PAGE. Human plasmin and thrombin were prepared by standard methods (22). Protein concentrations were measured by the method of Lowry et al. (23).

Cells. PMN of healthy adults were prepared from peripheral blood anticoagulated with $1 \mathrm{U} / \mathrm{ml}$ heparin by centrifugation through FicollPaque (Pharmacia Fine Chemicals, Piscataway, NJ) followed by sedimentation in $3 \%$ dextran in $0.15 \mathrm{M} \mathrm{NaCl}$ (24). Contaminating erythrocytes were removed by hypotonic lysis. These preparations contained 95-98\% neutrophils and 2-5\% eosinophils as assessed by microscopic inspection of Wright's-Giemsa-stained cytocentrifuge preparations. Viability was $>98 \%$ as assessed by trypan blue exclusion.

$P M N$ bactericidal activity. To assess bactericidal activity of PMN in the presence of BSA, Fbg, or FDP, a modification of the methods described by Steigbigel et al. (25) and Mandell (26) was used. Escherichia coli cultured in trypticase soy broth were washed in $0.15 \mathrm{M} \mathrm{NaCl}$ then incubated in $\mathrm{HBSS}$ and $10 \%$ normal human serum at $37^{\circ} \mathrm{C}$ for 30 min. After washing three times in HBSS, E. coli density was assessed by absorbance in a spectrophotometer. E. coli $\left(1 \times 10^{7}\right)$ and PMN $(5$ $\times 10^{6}$ ) were mixed in $0.7 \mathrm{ml}$ HBSS containing $50 \%$ vol/vol heat-inactivated FCS/HBSS/gelatin (Difco Laboratories Inc., Detroit, MI). 100 $\mu \mathrm{l}$ of heat-inactivated $\left(56^{\circ} \mathrm{C}\right.$ for $\left.1 \mathrm{~h}\right)$ normal human serum and $0.1 \%$ $\mathrm{vol} / \mathrm{vol}$ gelatin containing $50-100 \mu \mathrm{g} / \mathrm{ml} \mathrm{BSA}$, Fbg, or FDP were then added to triplicate tubes. PMN-bacterial mixtures were incubated at $37^{\circ} \mathrm{C}$ for $15 \mathrm{~min}$ with constant rotation. Extracellular organisms were killed by addition of $100 \mathrm{U} / \mathrm{ml}$ of penicillin and $100 \mu \mathrm{g} / \mathrm{ml}$ of streptomycin (Gibco Laboratories, Grand Island, NY) with continued rotation for $2 \mathrm{~h} .200-\mu \mathrm{l}$ aliquots from each tube were then removed, washed in $0.15 \mathrm{M} \mathrm{NaCl}, \mathrm{PMN}$ sonicated, and diluted $1: 1,000$ in HBSS. Triplicate $100-\mu \mathrm{l}$ aliquots of the diluted sonicates were plated on blood agar and bacterial colonies counted after incubation at $37^{\circ} \mathrm{C}$ for $24 \mathrm{~h}$.

$P M N$ phagocytosis. $0.5 \mathrm{ml}$ blood was placed on a coverslip and allowed to incubate for $90 \mathrm{~min}$ at $37^{\circ} \mathrm{C}$ in a humidified chamber. The formed clot was rinsed off the coverslip with $0.9 \% \mathrm{NaCl}$ and $10^{7} \mathrm{E}$. coli in $0.5 \mathrm{ml} \mathrm{NaCl}$ containing either $100 \mu \mathrm{g} / \mathrm{ml}$ BSA or FDP. Duplicate coverslips were incubated with added bacteria for 10,20 , or 30 min before washing with saline and fixation with $100 \%$ methanol. Phagocytosis was quantified in two ways: $(a)$ the proportion of PMN with ingested bacteria was determined by microscopic inspection of Giemsa-stained smears; and $(b)$ the number of ingested bacteria per PMN was calculated from the total number of $E$. coli counted in 100 PMN (27).

Superoxide production. Superoxide production was measured by SOD-inhibitable cytochrome $c$ reduction (28). PMN and cytochrome solution ( $1.2 \mathrm{mg}$ cytochrome $c / \mathrm{ml} \mathrm{HBSS}$ ) were added to glass cuvettes with a final concentration of $1 \times 10^{6} \mathrm{PMN} / \mathrm{ml}$ HBSS. The cells were incubated for $2 \mathrm{~min}$ with $10-100 \mu \mathrm{g} / \mathrm{ml}$ FDP or control BSA
( $<0.005 \%$ fatty acids) at $37^{\circ} \mathrm{C}$ (or other proteins listed in Results). FMLP, phorbol myristate acetate (PMA), AA, 1-oleoyl-2-acetylglycerol (OAG) diluted first in DMSO then PBS, zymosan-activated serum (containing C5a; ZAS) (29), or opsonized zymosan (30) (a phagocytic stimulus), were then added. Absorbance at $550 \mathrm{~nm}$ of triplicate samples was measured at 1-min intervals unless otherwise indicated. FMLP, OAG, AA, PMA, cytochrome $c$, and BSA were purchased from Sigma Chemical Co. In some experiments, stimuli were added to PMN suspensions 1.5 or 5.5 min after BSA, Fbg, or FDP. Preliminary experiments using acetaldehyde-xanthine oxidase to generate reduced oxygen products $(31)$ indicated that the amount of $\mathrm{O}_{2}^{-}$detected by the cytochrome $c$ reduction method was similar in buffer containing 100 $\mu \mathrm{g} / \mathrm{ml}$ BSA, Fbg, or FDP.

Chemotaxis. A modification of the chemotaxis under agarose assay (32) was used to assess chemotactic responses of PMN to FMLP in the presence of FDP, Fbg, or BSA. A layer of $0.6 \% \mathrm{wt} / \mathrm{vol}$ agarose was poured into plastic petri dishes and a circular array of wells cut into the gel using a standard template. PMN and either FDP or BSA (100 $\mu \mathrm{g} / \mathrm{ml})$ were placed in a middle well. FMLP $\left(1 \times 10^{-6} \mathrm{M}\right)$ or HBSS alone was then added to opposite outer wells. After $2 \mathrm{~h}$ incubation at $37^{\circ} \mathrm{C}$ in $5 \% \mathrm{CO}_{2}$ in air, the agar dishes were fixed with methanol and formalin, dried, and stained with Wright's-Giemsa for microscopic inspection. The chemotactic index was calculated by dividing the linear distance of the leading edge of PMN moving from the center well toward the outer well containing FMLP by the linear distance of PMN traveling toward the control well containing buffer alone.

Measurements of FMLP and phorbol ester binding to PMN. In the initial series of experiments PMN binding of FMLP was measured as described previously (33). Briefly, triplicate aliquots of $5 \times 10^{6} \mathrm{PMN}$ in $0.5 \mathrm{ml} \mathrm{HBSS}$ were preincubated for $2 \mathrm{~min}$ with $100 \mu \mathrm{g} / \mathrm{ml} \mathrm{Fbg}, \mathrm{BSA}$, or FDP at $25^{\circ} \mathrm{C}$. $1.7 \times 10^{-9} \mathrm{M}\left[{ }^{3} \mathrm{H}\right] \mathrm{FMLP}$ (specific activity $48.3 \mathrm{Ci}$ / mmol; New England Nuclear, Boston, MA) with or without 1,000-fold excess unlabeled FMLP was added and incubation continued for 30 min. PMN suspensions were then layered on silicone oil (PC550; Fluka AG, Ronkonkoma, NY) contained in plastic tubes and cell pellets obtained by centrifugation $(10,000 \mathrm{~g})$ for $2 \mathrm{~min}$. The bottom of the tube containing the cell pellet was cut off, placed in liquid scintillation counting fluid, and bound counts per minute determined by beta spectrometry. Specific binding of FMLP was calculated by subtraction of counts per minute bound in the presence of excess unlabeled FMLP from counts per minute in the absence of excess FMLP. Additional experiments were performed to examine whether FDP preferentially altered binding to high or low affinity PMN FMLP receptors. Internalization of chemotactic peptide receptors and FDP by PMN was minimized by carrying out 30 -min incubations at $4^{\circ} \mathrm{C}$ in HBSS containing $10 \mathrm{mM}$ sodium azide and $10 \mathrm{mM}$ 2-deoxyglucose (Sigma Chemical Co.) (34). 1.4-85 nM [ $\left.{ }^{3} \mathrm{H}\right] \mathrm{FMLP}(60.0 \mathrm{Ci} / \mathrm{mmol}$; Amersham Corp., Arlington Heights, IL) was incubated with triplicate samples of $2.5 \times 10^{6} \mathrm{PMN}$ in the presence of either $100 \mu \mathrm{g} / \mathrm{ml} \mathrm{BSA}$ or FDP. A 1,000-fold excess of unlabeled FMLP was added to determine nonspecific binding. Based on previous studies $(35,36)$, a two-site saturable model for FMLP receptors was assumed. Binding data were analyzed using NONLIN, a weighted nonlinear least squares regression computer program (37). To examine the concentration dependence of the possible effect of FDP on PMN FMLP binding, a similar assay was set up with $21 \mathrm{nM}\left[{ }^{3} \mathrm{H}\right] \mathrm{FMLP}$ as input and FDP concentrations ranging from 16 to $100 \mu \mathrm{g} / \mathrm{ml}$.

Phorbol ester binding to PMN was quantified by measurements of specific binding of $\left[{ }^{3} \mathrm{H}\right]$ phorbol-12,13-dibutyrate (PDBU) (38). PMN $\left(1 \times 10^{6}\right)$ were suspended in $200 \mu \mathrm{l} \mathrm{HBSS}$ at $25^{\circ} \mathrm{C}$ in plastic microtiter wells containing either $100 \mu \mathrm{g} / \mathrm{ml} \mathrm{BSA}$ or $100 \mu \mathrm{g} / \mathrm{ml} \mathrm{FDP.} 2 \times 10^{-7} \mathrm{M}$ $\left[{ }^{3} \mathrm{H}\right] \mathrm{PDBU}(18.9 \mathrm{Ci} / \mathrm{mmol}$; New England Nuclear) in the presence or absence of $5 \times 10^{-5} \mathrm{M}$ unlabeled PMA was added and incubation continued for $20 \mathrm{~min}$ at $37^{\circ} \mathrm{C}$. PMN in triplicate wells were then harvested on to glass filter paper and specific binding of $\left[{ }^{3} \mathrm{H}\right] \mathrm{PDBU}$ determined.

Binding of fluid-phase ligands to FDP and BSA. To determine whether FMLP, phorbol esters, or AA bound differentially to FDP vs. 
BSA, $1.7 \times 10^{-9} \mathrm{M}\left[{ }^{3} \mathrm{H}\right] \mathrm{FMLP}(48.3 \mathrm{Ci} / \mathrm{mmol}), 2 \times 10^{-7} \mathrm{M}\left[{ }^{3} \mathrm{H}\right] \mathrm{PDBU}$ $(18.9 \mathrm{Ci} / \mathrm{mmol})$, or $8.2 \times 10^{-7} \mathrm{M}\left[{ }^{3} \mathrm{H}\right] \mathrm{AA}(191 \mathrm{Ci} / \mathrm{mmol}$; Amersham Corp.) was incubated with BSA or FDP $(50 \mu \mathrm{g} / \mathrm{ml})$ in PBS for $1 \mathrm{~h}$ at $37^{\circ} \mathrm{C}$. The mixtures were then layered on a G-25 Sephadex column preequilibrated with excess BSA and 0.5-ml fractions eluted with PBS. The profile of protein elution was measured with a spectrophotometer $\left(A_{280}\right)$ and the pattern of ligand elution determined by beta spectrometry. The patterns of $\left[{ }^{3} \mathrm{H}\right]$-ligand coeluting with protein and free ligand were compared for BSA and FDP.

Effect of FDP on PKC activation by phorbol esters. The effect of FDP on PMN PKC activation was compared with that of BSA using the method of TerBush and Holz (39). PMN $\left(10^{7}\right)$ were incubated in HBSS with $10^{-8} \mathrm{M}$ PMA in the presence of either FDP or BSA $(100$ $\mu \mathrm{g} / \mathrm{ml}$ ) for $10 \mathrm{~min}$ at $37^{\circ} \mathrm{C}$. The cells were then washed three times in HBSS and resuspended in $0.4 \mathrm{ml}$ cold $\left(4^{\circ} \mathrm{C}\right)$ homogenizing buffer consisting of $139 \mathrm{mM}$ potassium glutamate, $20 \mathrm{mM}$ Pipes, $\mathrm{pH}$ 6.6, 5 mM EGTA, $5 \mathrm{mg} / \mathrm{ml} \mathrm{BSA}$, and $50 \mu \mathrm{g} / \mathrm{ml}$ leupeptin (KGEP) as described (40). The suspensions were sonicated twice (setting of 7 for $10 \mathrm{~s}$; Kontes Co., Vineland, NJ) and subjected to centrifugation at 148,000 $g$ for $10 \mathrm{~min}$. The supernatant (containing cytosol) was removed. The pellet (containing membranes) was washed twice in cold KGEP, resuspended in KGEP with trituration, and Triton X-100 added to both pellet and supernatant to a final concentration of $0.1 \% .20 \mu \mathrm{l}$ of each fraction was then added to a protein kinase $\mathrm{C}(\mathrm{PKC})$ assay solution containing $42 \mathrm{mM}$ potassium glutamate, $20 \mathrm{mM}$ Pipes (pH 6.6), 10 $\mathrm{mM} \mathrm{MgCl} 2,10 \mathrm{mM}$ DTT, $0.01 \%$ Triton X-100, $50 \mu \mathrm{g}$ histone $/ \mathrm{ml}, 0.8$ $\mathrm{mg} \mathrm{BSA} / \mathrm{ml}, \pm 0.8 \mathrm{mM} \mathrm{CaCl}_{2}, \pm 167 \mu \mathrm{g}$ phosphatidylserine $/ \mathrm{ml}, \pm 26.7$ $\mu \mathrm{g} \mathrm{1,2-diolein/ml} \mathrm{per} \mathrm{tube.} \mathrm{The} \mathrm{reaction} \mathrm{was} \mathrm{started} \mathrm{by} \mathrm{addition} \mathrm{of} 30$ mM [ ${ }^{32}$ P]ATP $(100,000 \mathrm{cpm}$; sp act, $23.8 \mathrm{Ci} / \mathrm{mmol}$; New England Nuclear) and incubation carried out for $10 \mathrm{~min}$ at $28^{\circ} \mathrm{C}$. The reaction was stopped by addition of $5 \%$ TCA, $0.25 \%$ sodium tungstate, $15 \mathrm{mM}$ $\mathrm{NaH}_{2} \mathrm{PO}_{4}$, and $2 \mathrm{mM}$ ATP. After addition of BSA and washing, the radioactivity in each of the precipitates from the PMN pellet fraction (membranes) and supernatant fraction (cytosol) was determined. PKC activity is defined as the difference between activity in $\mathrm{Ca}^{2+}$ and phosphatidylserine/diglyceride buffer vs. buffer without $\mathrm{Ca}^{2+}$ and phosphatidylserine/diglyceride. Results are expressed as picomoles phosphate incorporated/10 min per $10^{7} \mathrm{PMN}$. Comparisons of PKC activities in cytosolic (supernatant) and membrane (pellet) fractions were performed as a measure of translocation of PKC from the cytosol to membrane that occurs concomitantly with phorbol ester-induced cellular activation (41).

\section{Results}

PMN bactericidal and phagocytic activity in the presence of $F D P$. PMN incubated with $100 \mu \mathrm{g} / \mathrm{ml}$ FDP had significantly less (alpha $<0.05$, Wilcoxon-rank sum test) bactericidal activity for ingested $E$. coli compared with autologous cells mixed with an equivalent protein concentration of Fbg or BSA. Colony counts resulting from PMN preincubated with BSA ranged from 1 to 10 vs. 35 to 177 for those with FDP. FDP at a concentration of $50 \mu \mathrm{g} / \mathrm{ml}$ also significantly reduced the ability of PMN to kill $E$. coli (Table I). BSA, Fbg, or FDP had no effect on bacterial colony counts when PMN were omitted (data not shown). In contrast to the inhibitory effects of FDP on PMN bacterial killing, phagocytosis of $E$. coli was unaffected. In the presence of $100 \mu \mathrm{g} / \mathrm{ml} \mathrm{BSA}, 7,45$, and $85 \%$ of PMN contained ingested bacteria after 10,20 , and $30 \mathrm{~min}$, respectively. The respective values for PMN coincubated with $100 \mu \mathrm{g} / \mathrm{ml} \mathrm{FDP} \mathrm{were} 6,44$, and $90 \%$ (duplicate samples from a single donor). There was also no difference in the number of bacteria per PMN. At 10, 20, and $30 \mathrm{~min}$ of incubation the respective values for PMN/BSA mixtures were $0.08,2.85$, and 16.10 bacteria/cell vs. $0.06,3.30$, and 17.65 bacteria/cell for PMN/FDP mixtures.
Table I. Capacity of PMN To Exert Bactericidal Activity against $E$. coli in the Presence of BSA, Fbg, or FDP

\begin{tabular}{cccc}
\hline & \multicolumn{3}{c}{$\begin{array}{c}\text { Number of bacterial colonies* (PMN } \\
\text { coincubated with the following proteins) }\end{array}$} \\
\cline { 2 - 4 } Cell donor & BSA & Fbg & FDP \\
\hline 1 & $2^{\ddagger}$ & 4 & 177 \\
2 & 1 & 2 & 45 \\
3 & 10 & ND & 45 \\
4 & 3 & ND & 35 \\
5 & 3 & ND & 30 \\
\hline
\end{tabular}

* PMN $\left(5 \times 10^{6}\right)$ and $E$. coli $\left(\sim 10^{7}\right)$ were incubated in presence of BSA or FDP ( $100 \mu \mathrm{g} / \mathrm{ml}$ for cell donors $1-4$ and $50 \mu \mathrm{g} / \mathrm{ml}$ for donor 5) for $15 \mathrm{~min}$, noningested bacteria were killed by addition of penicillin and streptomycin, and incubation was continued for $2 \mathrm{~h}$ at $37^{\circ} \mathrm{C}(25,26)$. PMN were then sonicated, aliquots plated on blood agar, and bacterial colonies counted after incubation for $24 \mathrm{~h}$ at $37^{\circ} \mathrm{C}$. ${ }^{\ddagger}$ Results represent the mean of triplicates.

ND, not done.

Effects of plasma coagulant proteins on FMLP-stimulated $P M N \mathrm{O}_{2}^{-}$release. Incubation of PMN with FDP (10-100 $\mu \mathrm{g} / \mathrm{ml}), \mathrm{Fbg}(10-200 \mu \mathrm{g} / \mathrm{ml})$, plasmin $(10 \mu \mathrm{g} / \mathrm{ml})$, thrombin (1 or $10 \mathrm{U} / \mathrm{ml})$, or BSA $(100 \mu \mathrm{g} / \mathrm{ml})$ for $10 \mathrm{~min}$ did not result in detectable $\mathrm{O}_{2}^{-}$release. Cell viability as assessed by trypan blue exclusion was $>98 \%$ before and after addition of each of the proteins.

When $5 \times 10^{-7} \mathrm{M}$ FMLP was added to PMN suspended in $100 \mu \mathrm{g} / \mathrm{ml} \mathrm{BSA}, 2.5-22.5 \mathrm{nmol} \mathrm{O}-/ 10 \mathrm{~min}$ was released. Substitution of BSA with an equivalent concentration of FDP resulted in a 49-57\% reduction of FMLP-stimulated $\mathrm{O}_{2}^{-}$accumulation using PMN of six donors $(P<0.005$ by paired $t$ test, Fig. 2). The ranges for triplicate determinations represented by the mean values in this figure and Fig. 3 vary $<10 \%$ from the mean in every case. For example, the mean of $22.5 \mathrm{nmol}$ $\mathrm{O}_{2}^{-} / 10$ min (the highest point under CONT. in Fig. 2) was calculated from values ranging from 21 to $23 \mathrm{nmol} \mathrm{O}_{2}^{-} / 10 \mathrm{~min}$. In contrast to FDP, $\mathrm{Fbg}(100 \mu \mathrm{g} / \mathrm{ml})$, thrombin $(1$ or $50 \mathrm{U} / \mathrm{ml})$, or plasmin $(10 \mu \mathrm{g} / \mathrm{ml})$ did not affect the amount of FMLP-induced $\mathrm{PMN} \mathrm{O}_{2}^{-}$release compared with cells incubated with $100 \mu \mathrm{g} / \mathrm{ml} \mathrm{BSA}$ (range of 5 to $15 \mathrm{nmol} \mathrm{O}_{2}^{-} / 10 \mathrm{~min}$ in five experiments comparing coagulant proteins with BSA). The inhibitory effect of FDP on FMLP-induced $\mathrm{O}_{2}^{-}$release was not observed when FDP were removed before addition of the activating ligand. PMN were preincubated with $100 \mu \mathrm{g} / \mathrm{ml} \mathrm{FDP}$ for $10 \mathrm{~min}$ at $37^{\circ} \mathrm{C}$, washed three times in HBSS, and $5 \times 10^{-7}$ FMLP added. A total of $9.8,11.6$, and $13.0 \mathrm{nmol} \mathrm{O}_{2}^{-} / 10 \mathrm{~min}$



Figure 2. $\mathrm{PMN} \mathrm{O}_{2}^{-}$release induced by FMLP in the presence of $100 \mu \mathrm{g} / \mathrm{ml}$ BSA $(C O N T$.) or $100 \mu \mathrm{g} / \mathrm{ml}$ FDP. FMLP (5 $\left.\times 10^{-7} \mathrm{M}\right)$ was added to triplicate PMN samples for each cell donor 2 min after BSA or FDP. $P<0.005$ for CONT. vs. FDP. 


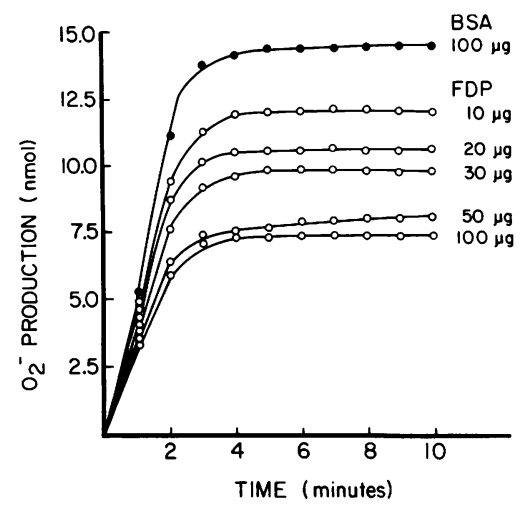

Figure 3. Kinetics of FMLP-induced PMN $\mathrm{O}_{2}^{-}$release in the presence of $10-100 \mu \mathrm{g} / \mathrm{ml}$ FDP (O) or $100 \mu \mathrm{g} / \mathrm{ml}$ BSA (๑). FMLP (5 $\left.\times 10^{-7} \mathrm{M}\right)$ was added to PMN 2 min after BSA or FDP. Results at each time point represent the mean of duplicate cell suspensions.

per $10^{6}$ cells (mean $\pm \mathrm{SE}$ of $11.4 \pm 0.9$ ) was released using PMN of three donors. Substitution of BSA for FDP in these experiments resulted in release of $10.2,11.1$, and $12.3 \mathrm{nmol} \mathrm{O}_{2}^{-}$, respectively (mean $\pm \mathrm{SE}$ of $11.2 \pm 0.6, P>0.05$ vs. FDP).

Results of studies examining the effects of various concentrations of FDP on FMLP-induced PMN $\mathrm{O}_{2}^{-}$release are presented in Fig. 3. Compared with control PMN incubated with $100 \mu \mathrm{g} \mathrm{BSA} / \mathrm{ml}$, concentrations of 10,20 , and $50 \mu \mathrm{g} \mathrm{FDP} / \mathrm{ml}$ inhibited $\mathrm{PMN} \mathrm{O}_{2}^{-}$released over $10 \mathrm{~min}$ by 17,35 , and $50 \%$, respectively. The maximal rate of $\mathrm{O}_{2}^{-}$release (calculated from the steepest portion of the curve representing change in absorbance vs. time) also decreased progressively in the presence of increasing concentrations of FDP $(15,23,32,42$, and $48 \%$ reductions with $10,20,30,50$, and $100 \mu \mathrm{g} / \mathrm{ml} \mathrm{FDP).} \mathrm{Further}$ inhibition was not observed when $200 \mu \mathrm{g} / \mathrm{ml}$ FDP was added (data not shown). Similar results were obtained using cells from two other donors. No difference in FMLP-induced PMN $\mathrm{O}_{2}^{-}$release was observed in the presence of equivalent concentrations of Fbg or BSA.

To determine whether the inhibitory effect of FDP could be reversed by increasing the amount of stimulating ligand, PMN were preincubated for 2 min with $100 \mu \mathrm{g} \mathrm{BSA} / \mathrm{ml}$ (control) or $100 \mu \mathrm{g} \mathrm{FDP} / \mathrm{ml}$ and increasing amounts of FMLP added. When $1 \times 10^{-7} \mathrm{M}$ FMLP was added, 50\% inhibition of $\mathrm{PMN} \mathrm{O}_{2}^{-}$release was produced by FDP $(11 \pm 2 \mathrm{nmol} / 10 \mathrm{~min}$ for FDP vs. $22 \pm 3 \mathrm{nmol} / 10 \mathrm{~min}$ in BSA controls, mean \pm SE of experiments using PMN of three individuals). A similar degree of FDP-induced inhibition (62\%) occurred when the FMLP concentration was increased to $5 \times 10^{-7} \mathrm{M}\left(16 \mathrm{nmol} \mathrm{O}_{2}^{-} / 10\right.$ min with FDP vs. $42 \mathrm{nmol} / 10$ min with BSA). Less inhibition was observed when the concentration of FMLP was increased to $1 \times 10^{-6} \mathrm{M}$. In two experiments control PMN released $58 \pm 4$ and $60 \pm 2 \mathrm{nmol} \mathrm{O}_{2}^{-} / 10 \mathrm{~min}$ vs. $51 \pm 1$ and $56 \pm 4 \mathrm{nmol} / 10$ $\mathrm{min}$ in the presence of FDP ( 25 and $16 \%$ inhibition, respectively).

As a first step in defining the specific proteins in FDP responsible for suppression of PMN responses, PMN were preincubated with purified fragments $D_{1}$ or $E_{3} 2$ min before addition of $5 \times 10^{-7} \mathrm{M}$ FMLP. Release of $\mathrm{O}_{2}^{-}$from PMN preincubated with $10 \mu \mathrm{g} / \mathrm{ml} \mathrm{BSA}$ (controls) was $20.0 \pm 1.0$ $\mathrm{nmol} / 10 \mathrm{~min}$. In the presence of $10 \mu \mathrm{g} / \mathrm{ml}$ fragment $D_{1}$ or $E_{3}$ these values were, respectively, $20.0 \pm 1.5$ and $14.1 \pm 2.0 \mathrm{nmol}$ $\mathrm{O}_{2}^{-} / 10$ min (mean $\pm \mathrm{SD}$ for triplicate determinations of PMN of one donor; $P<0.05$ for fragment $E_{3}$ vs. controls). Using PMN of a second donor preincubated with $50 \mu \mathrm{g} / \mathrm{ml} \mathrm{BSA}$ or fragment $D_{1}, O_{2}^{-}$release over $10 \mathrm{~min}$ was, respectively, $16.1 \pm 1.0$ and $16.0 \pm 2.0 \mathrm{nmol}$. In contrast, fragment $E_{3}$ at a

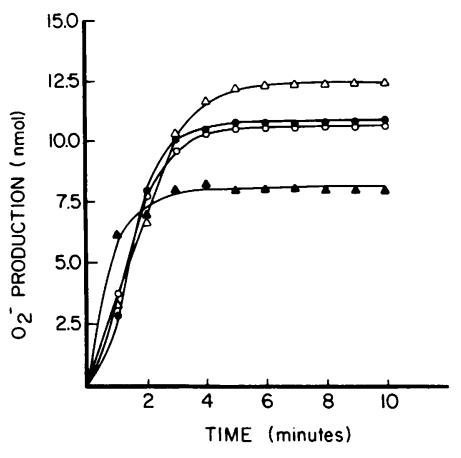

Figure 4. Effect of time of addition of FDP or BSA on kinetics of FMLP-stimulated $\mathrm{PMN} \mathrm{O}_{2}^{-}$release. 5 $\times 10^{-7} \mathrm{M}$ FMLP was added to $P M N$ at time 0 . BSA $(100 \mu \mathrm{g} / \mathrm{ml})$ was added $1.5(\bullet)$ or $5.5 \mathrm{~min}$ (O) later. In parallel studies, FDP $(100 \mu \mathrm{g} / \mathrm{ml})$ was added $1.5(\Delta)$ or $5.5 \mathrm{~min}$ $(\Delta)$ later. Results represent the mean of triplicate determinations at each time point.

concentration of $50 \mu \mathrm{g} / \mathrm{ml}$ suppressed $\mathrm{O}_{2}^{-}$release from PMN of a third donor by $21 \%(29.1 \pm 3.0$ in the presence of $50 \mu \mathrm{g} / \mathrm{ml}$ BSA vs. $22.0 \pm 3.0 \mathrm{nmol} / 10 \mathrm{~min}, P<0.05$ ).

Capacity of FDP to reverse FMLP-induced PMN $\mathrm{O}_{2}^{-}$release. To ascertain whether FDP could abrogate $\mathrm{O}_{2}^{-}$production from PMN previously exposed to FMLP, $100 \mu \mathrm{g} / \mathrm{ml} \mathrm{FDP}$ or control BSA was added to cells 1.5 or $5.5 \mathrm{~min}$ after $5 \times 10^{-7}$ M FMLP. Addition of BSA 1.5 (Fig. 4, closed circles) or 5.5 min (open circles) after FMLP did not have a differential effect on the rate or accumulation of $\mathrm{O}_{2}^{-}$generated by PMN $\left(10.5 \pm 1.0 \mathrm{nmol} \mathrm{O}_{2}^{-}\right.$over $10 \mathrm{~min}$, mean $\pm \mathrm{SD}$ of triplicate determinations). In contrast, addition of FDP $1.5 \mathrm{~min}$ after FMLP (closed triangles) resulted in an immediate decrease in the rate and accumulation of $\mathrm{O}_{2}^{-}$compared with addition at $5.5 \mathrm{~min}$ (open triangles) $(7.5 \pm 0.5 \mathrm{nmol} / 10 \mathrm{~min}$ vs. $12.5 \pm 1.5 \mathrm{nmol} /$ $10 \mathrm{~min}$ ).

Binding of fluid-phase FMLP by FDP. Results reported thus far are consistent with a mechanism whereby FDP bind fluid-phase FMLP more effectively than BSA, thereby preventing interaction of the stimulus with its cellular target. To examine this possibility, equivalent concentrations $(50 \mu \mathrm{g} / \mathrm{ml})$ of FDP or BSA were incubated with radiolabeled FMLP and the proportions of protein-bound vs. free ligand compared. $100 \%$ of added radiolabel coeluted with free ligand for mixtures of FMLP/BSA and FMLP/FDP. FMLP thus did not appear to bind to either protein.

Effect of FDP on PMN binding of FMLP. Because our previous experiments demonstrated that the effects of FDP on FMLP-induced $\mathrm{PMN} \mathrm{O}_{2}^{-}$release occurred when the proteins were added subsequent to ligand (Fig. 4) and were not secondary to removal of fluid-phase FMLP by protein binding, we next evaluated the possibility that FDP interferes with interaction of FMLP with the PMN surface. In experiments using cells of four donors, FMLP binding was $72 \pm 12 \%$ (mean \pm SE) lower in the presence of $100 \mu \mathrm{g} / \mathrm{ml}$ FDP compared with an equivalent concentration of BSA ( $1.7 \mathrm{nM}$ input of $\left.\left[{ }^{3} \mathrm{H}\right] \mathrm{FMLP}\right)$ (Table II). There were no differences in the effects of Fbg and BSA on PMN binding of FMLP (Table II). To define in more detail the possible interaction of FDP with FMLP receptors, additional experiments were performed in conditions limiting PMN internalization of FMLP and coagulant proteins and over a broad concentration range of radiolabeled ligand (1.3-85 nM [ $\left.{ }^{3} \mathrm{H}\right]$ FMLP). In the presence of $100 \mu \mathrm{g} / \mathrm{ml}$ BSA (control protein), PMN were calculated to have high affinity FMLP receptors with $K_{\mathrm{d}}=2.8 \times 10^{-9} \mathrm{M}$ and low affinity receptors with $K_{\mathrm{d}}=1.5 \times 10^{-7} \mathrm{M}$ (curve generated from triplicate determinations of six points) (Fig. 5). Parallel studies con- 
Table II. Effect of FDP on PMN Binding of FMLP and PDBU

\begin{tabular}{ccccc}
\hline & & \multicolumn{3}{c}{ Specific binding of ligand } \\
\cline { 3 - 5 } Cell donor & Ligand & BSA $(100 \mu \mathrm{g} / \mathrm{ml})$ & Fbg $(100 \mu \mathrm{g} / \mathrm{ml})$ & FDP $(100 \mu \mathrm{g} / \mathrm{ml})$ \\
\hline & & \multicolumn{4}{c}{$c p m$} \\
1 & FMLP* & 24,000 & 25,200 & $12,022(50)^{\ddagger}$ \\
2 & FMLP & 10,980 & 11,053 & $5,421(51)$ \\
3 & FMLP & 1,090 & ND & $245(88)$ \\
4 & FMLP & 2,301 & ND & $48(98)$ \\
5 & PDBU & 7,099 & ND & $7,836(0)$ \\
6 & PDBU & 5,560 & ND & $6,900(0)$ \\
& & & & \\
\hline
\end{tabular}

* $\left[{ }^{3} \mathrm{H}\right]$ FMLP $\left(1.7 \times 10^{-9} \mathrm{M}\right)$ was incubated in the presence or absence of 1,000-fold excess unlabeled FMLP with BSA, Fbg, or FDP to measure specific binding (32). Results represent the mean of triplicate determinations for each cell donor.

¥ Percent reduction compared with BSA.

${ }^{8}\left[{ }^{3} \mathrm{H}\right] \mathrm{PDBU}\left(2 \times 10^{-7} \mathrm{M}\right)$ was incubated in the presence or absence of 250-fold excess unlabeled PMA with BSA or FDP $(100 \mu \mathrm{g} / \mathrm{ml})$ to measure specific binding (38). Results represent the mean of duplicate determinations for each cell donor.

ND, not done.

ducted with $100 \mu \mathrm{g} / \mathrm{ml}$ FDP showed that FMLP binding was reduced $>90 \%$ in both the steep and flat portions of the curve generated by the Scatchard plot (Fig. 5). Additional binding studies showed that lower concentrations of FDP also inhibited PMN-FMLP interaction. When the total protein concentration was kept constant at $100 \mu \mathrm{g} / \mathrm{ml}$, increasing the proportion of FDP:BSA from 16 to $25 \%$ resulted in respective reductions of specific FMLP binding of 44 and $80 \%$ compared with samples containing BSA alone (mean of triplicate samples at each point, Fig. 6). Greater reduction in specific radiolabeled ligand binding was not demonstrable when the FDP concentration was increased to 50 or $100 \mu \mathrm{g} / \mathrm{ml}(85 \%$ decreases in binding compared with PMN coincubated with $100 \mu \mathrm{g} / \mathrm{ml}$ BSA and no FDP) (Fig. 6). The input of $\left[{ }^{3} \mathrm{H}\right]$ FMLP in these experiments was $21 \mathrm{nM}$.

FDP and other procoagulant protein effects on FMLP-stimulated PMN chemotaxis. FMLP-stimulated chemotaxis was used as an additional functional assay, independent of oxidative metabolism, to confirm that FDP interfered with ligand binding to PMN. In experiments using cells from four donors,

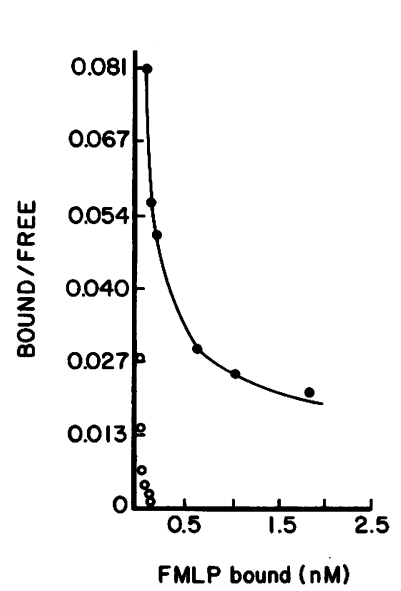

Figure 5. Scatchard plot of FMLP binding to $\mathrm{PMN}$ in the presence of $100 \mathrm{mg} / \mathrm{ml} \mathrm{BSA}$ or FDP. Specific binding FMLP was measured in conditions that minimize internalization of ligand as previously described $(34,35)$. Each point represents the mean of triplicate determinations. Curves were generated according to NONLIN computer program with a two-site model of FMLP binding assumed (36). Closed circles represent FMLP binding in the presence of $100 \mathrm{mg} / \mathrm{ml} \mathrm{BSA}$. Open circles represent binding in the presence of $100 \mathrm{mg} / \mathrm{ml}$ FDP.

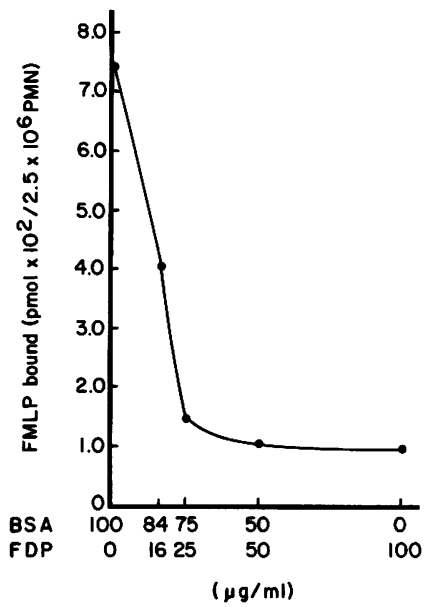

FDP reduced directed migration of PMN by $32-48 \%$ compared with BSA. A chemotactic index of $3.4 \pm 0.4$ (mean \pm SE) was obtained for control PMN incubated with BSA vs. $2.0 \pm 0.3$ for those with FDP $(P<0.01)$ (Table III). The chemotactic indices of PMN incubated with $\mathrm{Fbg}(100 \mu \mathrm{g} / \mathrm{ml})$, thrombin (50 $\mathrm{U} / \mathrm{ml})$, or plasmin $(10 \mu \mathrm{g} / \mathrm{ml})$ did not differ significantly from controls (data not shown for latter two proteins).

FDP modification of $P M N \mathrm{O}_{2}^{-}$release induced by additional nonphagocytic and phagocytic stimuli. To examine whether the inhibitory effect of FDP occurred under circumstances involving other nonphagoytic stimuli, studies were conducted with PMA, OAG, AA, and ZAS. PMA and OAG may stimulate the respiratory burst primarily through direct activation and translocation of PKC (41), while the mechanism by which AA induces $\mathrm{PMN} \mathrm{O}_{2}^{-}$release is not well established (42). ZAS containing C5a presumably stimulates PMN respiratory burst activity by a pathway similar to that for other ligands having surface $P M N$ receptors (e.g., FMLP). When 10 $\mathrm{ng} / \mathrm{ml}$ PMA was added to $\mathrm{PMN}, \mathrm{O}_{2}^{-}$release was $20-74 \%$ lower in the presence of $100 \mu \mathrm{g} / \mathrm{ml}$ FDP vs. an equal concentration of BSA $(P<0.001$, Table IV). Unlike the situation with FMLP, however, addition of FDP 1.5 min after PMA did not inhibit $\mathrm{PMN} \mathrm{O}_{2}^{-}$release (data not shown). Stimulation of

Table III. FMLP-induced PMN Chemotaxis in the Presence of $B S A, F b g$, or FDP

\begin{tabular}{cccc}
\hline & \multicolumn{3}{c}{$\begin{array}{c}\text { Chemotactic index } \\
\text { (Protein [100 } \mu \mathrm{g} / \mathrm{ml} \text { ] added to PMN) }\end{array}$} \\
\cline { 2 - 4 } PMN donor & BSA & Fbg & FDP \\
\hline 1 & $2.1^{*}$ & 2.3 & $1.1(48)^{\ddagger}$ \\
2 & 4.1 & 3.2 & $2.4(41)$ \\
3 & 3.8 & ND & $2.6(32)$ \\
4 & 3.7 & ND & $2.1(43)$ \\
Mean \pm SE & $3.4 \pm 0.4$ & ND & $2.0 \pm 0.3(41)^{8}$
\end{tabular}

* Results represent the mean of triplicate determinations using a chemotaxis in agarose technique (32).

${ }^{\ddagger}$ This value is the percent inhibition compared with PMN incubated with BSA.

The mean value for PMN preparations incubated with FDP was significantly less compared with controls (BSA) with $P<0.01$. ND, not done. 
Table IV. Effect of FDP on PMA-stimulated PMN $\mathrm{O}_{2}$ Release

\begin{tabular}{cccc}
\hline & \multicolumn{3}{c}{ Maximal rate of $\mathrm{O}_{2}^{-}$release } \\
\cline { 2 - 4 } Experiment & BSA $(100 \mu \mathrm{g} / \mathrm{ml})$ & FDP $(100 \mu \mathrm{g} / \mathrm{ml})$ & \% Inhibition by FDP \\
\hline \multicolumn{4}{c}{$n \mathrm{~mol} / \mathrm{min}$} \\
1 & $6.8^{*}$ & 1.8 & 74 \\
2 & 3.5 & 2.2 & 37 \\
3 & 8.8 & 5.6 & 36 \\
4 & 8.7 & 7.0 & 20 \\
5 & 8.1 & 4.9 & 39 \\
6 & 7.0 & 4.8 & 31 \\
& & & \\
\hline
\end{tabular}

PMN were incubated with $100 \mu \mathrm{g} / \mathrm{ml} \mathrm{BSA}$ or FDP at $37^{\circ} \mathrm{C}$ and 10 $\mathrm{ng} / \mathrm{ml}$ PMA added 2 min later. Maximal rates were calculated from the steepest portion of curve generated by absorbance readings taken at 1 -min intervals (28).

* Results represent the mean of triplicate determinations.

$\mathrm{PMN} \mathrm{O}_{2}^{-}$release induced by OAG was also inhibited by FDP. PMN preincubated with $100 \mu \mathrm{g} \mathrm{BSA} / \mathrm{ml}$ for $2 \mathrm{~min}$ followed by addition of $10^{-6} \mathrm{M}$ OAG released $8.9 \pm 0.4 \mathrm{nmol} \mathrm{O}-120 \mathrm{~min}$ (mean \pm SD of triplicate determinations), whereas those preincubated with $100 \mu \mathrm{g} F D P / \mathrm{ml}$ released $3.3 \pm 0.6 \mathrm{nmol}(P$ $<0.01)$. AA $\left(4.2 \times 10^{-5} \mathrm{M}\right)$-induced $\mathrm{O}_{2}^{-}$release was also reduced by FDP. PMN of two donors stimulated with AA released 20.0 and $19.0 \mathrm{nmol} \mathrm{O}_{2}^{-} / 10 \mathrm{~min}$ per $10^{6}$ cells in the presence of $100 \mu \mathrm{g} / \mathrm{ml} \mathrm{BSA}$ vs. 8.4 and $8.0 \mathrm{nmol} / 10 \mathrm{~min}$, respectively, when an equivalent concentration of FDP was included. Addition of FDP to PMN 1.5 min after AA did not affect $\mathrm{O}_{2}^{-}$release, as reported for PMA. Addition of $20 \mu \mathrm{l}$ ZAS to $10^{6} \mathrm{PMN}$ suspended in $1 \mathrm{ml}$ buffer containing $100 \mu \mathrm{g} / \mathrm{ml}$ Fbg resulted in generation of $1.3 \pm 0.4 \mathrm{nmol} \mathrm{O} \mathrm{O}_{2}^{-}$over a 10 -min period (triplicate samples). When the same individual's PMN were stimulated simultaneously with ZAS in the presence of 10,50 , or $100 \mu \mathrm{g} / \mathrm{ml} \mathrm{FDP} \mathrm{(the} \mathrm{remaining} \mathrm{protein} \mathrm{in} \mathrm{the} \mathrm{former}$ two samples consisted of $\mathrm{Fbg}$ ), the amount of $\mathrm{O}_{2}^{-}$released decreased to $1.1 \pm 0.1,1.0 \pm 0.2$, and $0.9 \pm 0.1 \mathrm{nmol} \mathrm{O}_{2}^{-}$.

In contrast to the inhibitory effects of FDP on $\mathrm{PMN} \mathrm{O}_{2}^{-}$ release induced by these nonphagocytic stimuli, $\mathrm{O}_{2}^{-}$release induced by phagocytosis of opsonized zymosan was not altered. $50 \mu \mathrm{l}$ opsonized zymosan was added to PMN coincubated with either $100 \mu \mathrm{g} / \mathrm{ml} \mathrm{BSA}$ or FDP. The mean amounts of $\mathrm{O}_{2}^{-}$released over a $30-\mathrm{min}$ period in the presence of BSA vs. FDP were, respectively, 14.6 vs. $15.8,2.6$ vs. 5.3 , and 21.9 vs. $17.4 \mathrm{nmol}$ (cells of three individuals, $P>0.05$ ).

Effect of FDP on AA and phorbol ester binding to PMN. We determined first whether FDP bound fluid-phase phorbol ester or AA to a greater extent than BSA. In the case of $\left[{ }^{3} \mathrm{H}\right] \mathrm{PDBU}$, $100 \%$ of radiolabel coeluted with free ligand after preincubation with BSA or FDP, as described for FMLP. In contrast, AA bound to both BSA and FDP. Coincubation of $\left[{ }^{3} \mathrm{H}\right] \mathrm{AA}$ with BSA for $1 \mathrm{~h}$ resulted in $55.9 \%$ of radiolabel being protein bound and $44.1 \%$ unbound. When FDP was substituted, $2.2 \%$ of radiolabel bound to protein vs. $97.8 \%$ unbound. These data indicate that BSA binds AA to a greater extent than FDP in our assay conditions. To ascertain whether FDP also reduced PMN binding of phorbol esters as reported for FMLP, specific binding of $\left[{ }^{3} \mathrm{H}\right] \mathrm{PDBU}$ was measured in the presence of BSA or FDP $(100 \mu \mathrm{g} / \mathrm{ml})$. Similar amounts of PDBU were specifically
Table V. Effect of FDP on Activation and Translocation of PMN PKC

\begin{tabular}{llll}
\hline & & \multicolumn{2}{c}{ PKC activity* } \\
\cline { 3 - 3 } Donor & Protein & \multicolumn{1}{c}{ Unstimulated } & PMA stimulated \\
\hline & & \multicolumn{2}{c}{$p$ mol P/10 min per $10^{7} P M N$} \\
F.H. & BSA & $410 \pm 31^{\ddagger}(75)^{\S}$ & $581 \pm 19^{\| 1}(25)$ \\
& FDP & $500 \pm 27(65)$ & $490 \pm 20(59)$ \\
J.K. & BSA & $498 \pm 53(67)$ & $613 \pm 28^{\S}(35)$ \\
& FDP & $491 \pm 29(72)$ & $486 \pm 25(63)$
\end{tabular}

* PMN were incubated with $100 \mu \mathrm{g} / \mathrm{ml}$ BSA or FDP and PKC activity was measured after exposure to buffer alone (unstimulated) or $10^{-8}$ PMA $(39,40)$.

₹ This value represents the mean of triplicate determinations.

${ }^{8}$ The number within the parentheses represents the percent PKC activity in the soluble (cytoplasmic) fraction of PMN sonicates subjected to centrifugation at $148,000 \mathrm{~g}$ for $10 \mathrm{~min}$.

" $P<0.05$ compared with unstimulated PMN.

bound by PMN when the assay was performed in the presence of BSA or FDP (Table II).

PKC activation. FDP completely abrogated PKC activation by PMA in intact PMN. When $10^{-8} \mathrm{M}$ PMA was added to PMN coincubated with $100 \mu \mathrm{g} / \mathrm{ml}$ FDP, there was no change in total PKC activity or the proportion in soluble fractions of PMN sonicates (65 and $72 \%$ for unstimulated cells). In contrast, when PMN were coincubated with $100 \mu \mathrm{g} / \mathrm{ml} \mathrm{BSA,} \mathrm{PMA}$ caused a $23-41 \%$ increase in total PKC activity $(P<0.05)$ and one-third to one-half reduction in the proportion in soluble fractions (Table V). Cells not exposed to protein or PMA had values that were identical to those incubated with BSA (e.g., $400 \pm 35 \mathrm{pmol} P / 10$ min per $10^{7} \mathrm{PMN}$ with no protein or PMA vs. $380 \pm 40 \mathrm{pmol} \mathrm{P} / 10 \mathrm{~min}$ per $10^{7} \mathrm{PMN}$ with $100 \mu \mathrm{g} / \mathrm{ml} \mathrm{BSA}$; triplicate samples for each with cells of one donor).

\section{Discussion}

Fbg and several proteolytic fragments of this plasma protein have important effects on circulating PMN. Low molecular weight $(<20 \mathrm{kD})$ fragments produced by extensive plasmin digestion are chemotactic for rabbit PMN in vitro and induce egress from the vascular space in vivo $(43,44)$. Fibrinopeptide $\mathrm{B}$, a thrombin-derived cleavage product of Fbg BB chains, is also chemotactic but does not stimulate degranulation or respiratory burst activity (16). The possible alterations in PMN function mediated by FDP $D$ and $E$, the major FDP elevated in plasma of persons with DIC and predisposing conditions such as adult respiratory distress syndrome (45-47) have, however, not been studied. The current results indicate that FDP D and $\mathrm{E}$ at concentrations similar to those observed in DIC significantly impair the capacity of PMN to kill $E$. coli in vitro. This defect in bactericidal function is apparently related to alterations in intraphagolysosomal function since bacterial phagocytosis and extracellular release of $\mathrm{O}_{2}^{-}$induced by phagocytic stimulation (opsonized zymosan) were unaffected by FDP. To define the possible basis of the FDP inhibitory effect on PMN bactericidal function, a series of studies using ligands that elicit relevant PMN responses by initially occupying sur- 
face-exposed receptors (i.e., FMLP or C5a) or by directly binding and activating PKC (PMA and possibly AA) were conducted.

Several aspects of the PMN response to FMLP are inhibited by FDP but unaffected by thrombin, plasmin, or Fbg. Superoxide production decreases in a dose-dependent manner upon addition of $10-100 \mu \mathrm{g} / \mathrm{ml}$ of fragments D and E. Comparison of the capacities of purified preparations of fragments $D_{1}$ and $E_{3}$ to affect FMLP-stimulated $P M N O_{2}^{-}$production suggests that the latter fraction is responsible for the inhibitory effect of FDP. These experiments have not excluded the possibility that higher concentrations of fragment $D_{1}$ than those used here $(50 \mu \mathrm{g} / \mathrm{ml})$ might also be inhibitory. As a first step in dissecting the possible mechanism of FDP inhibition of FMLP-stimulated $\mathrm{PMN} \mathrm{O}_{2}^{-}$release, we examined the reversibility of the effect. Whereas preincubation of cells with FDP followed by washing failed to alter FMLP-induced $\mathrm{O}_{2}^{-}$release, addition of FDP 1.5 min after FMLP resulted in immediate curtailment of oxyradical accumulation. Since continual occupancy of FMLP receptors is required for optimal stimulation of $\mathrm{PMN} \mathrm{O}_{2}^{-}$release $(48,49)$, these results suggest that FDP. disrupts the interaction of FMLP with its corresponding cellular receptors. The ability of FDP to inhibit FMLP-induced PMN chemotaxis without binding directly to fluid-phase ligand is also consistent with a process involving impairment of cellular receptor-FMLP interaction. To examine this event directly, specific binding of $\left[{ }^{3} \mathrm{H}\right] \mathrm{FMLP}$ to $\mathrm{PMN}$ was measured. FDP inhibited FMLP binding (1.7 nM input) by $50-98 \%$. The inhibitory effect occurred at FDP concentrations as low as 16 $\mu \mathrm{g} / \mathrm{ml}$ and was maximal at $\geq 25 \mu \mathrm{g} / \mathrm{ml}$. Chemotactic binding studies performed over a broad concentration range of $\left[{ }^{3} \mathrm{H}\right] \mathrm{FMLP}$ in conditions that minimize receptor internalization showed that FDP reduced FMLP binding at all levels of $\left[{ }^{3} \mathrm{H}\right]$-ligand input. These results suggest that FDP do not interfere preferentially with FMLP interaction with high or low affinity PMN chemotactic peptide receptors. However, more detailed studies using multiple concentrations of FMLP input are required to confirm this. It is also not possible on the basis of these data to distinguish among the possible mechanisms by which FDP interfere with FMLP binding to PMN, e.g., occupancy of the FMLP binding site(s), steric hindrance, alterations in surface receptor mobility, and/or stabilization of the receptor-ligand complex (50).

The effects of $\mathrm{Fbg}$ fragments $\mathrm{D}$ and $\mathrm{E}$ on PMN oxidative metabolism are not limited to FMLP stimulation. Production of $\mathrm{O}_{2}^{-}$induced by PMA, AA, and OAG are also significantly reduced by FDP. The pathways by which these stimuli induce $\mathrm{PMN} \mathrm{O}_{2}^{-}$release are the subject of a great deal of study and have not been completely elucidated. These molecules are lipophilic and rapidly interact with the PMN plasma membrane. PMA and probably OAG bind directly to PKC $(41,51$, 52) and induce translocation of the enzyme from the cytosol to plasma membrane (51). This process is concurrent with activation of the enzyme(s) involved in the initial one electron reduction of $\mathrm{O}_{2}$ (41). Although the mechanisms by which AA activates the respiratory burst have not been well defined, this lipid may alter surface membrane fluidity $(53,54)$, directly activate PKC in some circumstances $(55,56)$, and is a required cofactor for NADPH oxidase activity prepared from broken resting PMN $(57,58)$. The current studies indicate that FDP inhibition of respiratory burst activity induced by these stimuli is not attributable to protein binding of fluid-phase ligands or interference with phorbol ester binding to PMN. Rather, our observations are consistent with the possibility that FDP impair activation and translocation of PKC from the PMN cytosolic to membrane fraction. Further studies to examine this include direct measures of PMN membrane fluidity in the presence of FDP and determination of whether FDP influences activation of PKC isolated from broken cells.

By analogy with the functional consequences of Fbg interaction with platelets $(2,5,6)$, it might be expected that the observed effects of FDP on PMN activities are in part related to occupancy of $\mathrm{Fbg}$ binding sites. Although there are data indicating that promyeloid U937 cells possess GP IIb/IIIa, the molecular complex that represents the platelet $\mathrm{Fbg}$ receptor (59), recent reports suggest that circulating human PMN specifically bind $\mathrm{Fbg}$ via receptors that are similar or possibly identical to those for high molecular weight kininogen (60). Detailed molecular characterization of the interaction of FDP $D$ and $E$ with PMN and their functional effects on cells will require isolation of these receptor sites and use of highly purified preparations of fragments $D_{1}$ and $E_{3}$. Finally, the role of PMN proteases in modifying cellular responses to Fbg and FDP needs to be investigated $(61,62)$. The relevance of such molecules to PMN function has been suggested by recent observations of Wachtfogel and co-workers, who showed that fibronectin degradation products containing cytoadhesive peptide sequences identical to those in FDP (63) induce release of neutrophil elastase (64).

\section{Acknowledgments}

The authors wish to thank Pedro de Brito and Sue Hudson for technical assistance and Pat Amato for typing the manuscript.

This work was supported by National Institutes of Health grants HL-37117 and HL-34641.

\section{References}

1. Weiss, H. J., and J. Rogers. 1971. Fibrinogen and platelets in the primary arrest of bleeding. $N$. Engl. J. Med. 285:369-374.

2. Peerschke, E. I., M. G. Zucker, R. A. Grant, J. J. Egan, and M. M. Johnson. 1980. Correlation between fibrinogen binding to human platelets and platelet aggregability. Blood. 55:841-847.

3. Marguerie, G. A., E. F. Plow, and T. S. Edgington. 1979. Human platelets possess an inducible and saturable receptor specific for fibrinogen. J. Biol. Chem. 154:5357-5363:

4. Ruggeri, Z. M., R. A. Houghten, S. R. Russell, and T. S. Zimmerman. 1986. Inhibition of platelet function with synthetic peptides designed to be high affinity antagonists of fibrinogen binding to platelets. Proc. Natl. Acad. Sci. USA. 83:5708-5712.

5. Peerschke, E. I. 1985. The platelet fibrinogen receptor. Semin. Hematol. 22:241-259.

6. Niewiarowski, S., E. Kornecki, A. Z. Budzynski, T. A. Morinelli, and G. P. Tuszynski. 1983. Fibrinogen interaction with platelet receptors. Ann. NY Acad. Sci. 408:536-555.

7. Rowland, F. N., M. J. Donovan, P. T. Picciano, G. D. Wilner, and D. L. Krentzer. 1984. Fibrin-mediated vascular injury: identification of fibrin peptides that mediate endothelial cell retraction. Am. J. Pathol. 117:418-428.

8. Dang, C. V., W. R. Bell, D. Kaiser, and A. Wong. 1985. Disorganization of cultured vascular endothelial cell monolayers by fibrinogen fragment D. Science (Wash. DC): 227:1487-1490.

9. Dejana, E., M. Vergara-Davden, G. Balconi, A. Pietra, G. Cherel, M. B. Conati, M. Larrieu, and G. Marguerie. 1984. Specific binding of human fibrinogen to cultured human fibroblasts: evidence for involvement of the E domain. Eur. J. Biochem. 139:657-662. 
10. Grinnel, F., M. Feld, and D. Minter. 1980. Fibroblast adhesion to fibrinogen and fibrin substrata: requirement for cold-insoluble globulin (plasma fibronectin). Cell. 19:517-525.

11. Girmann, G., H. Pees, G. Schwarze, and P. G. Scheurlen. 1976. Immunosuppression by micromolecular fibrinogen degradation products in cancer. 1976. Nature (Lond.). 259:399-401.

12. Edgington, T. S., L. K. Curtis, and E. F. Plow. 1985. A linkage between the hemostatic and immune systems embodied in the fibrinolytic release of lymphocyte suppressive peptides. J. Immunol. 134:471-477.

13. Stecher, V. J., and E. Sorkin. 1972. The chemotactic activity of fibrin lysis products. Int. Arch. Allergy Appl. Immunol. 43:879-886.

14. McKenzie, R., D. S. Pepper, and A. B. Kay. 1974. The generation of chemotactic activity for human leukocytes by the action of plasmin on human fibrinogen. Thromb. Res. 6:1-8.

15. Richardson, D. L., D. S. Pepper, and A. B. Kay. 1976. Chemotaxis for human monocytes by fibrinogen-derived peptides. Br. J. Haematol. 32:507-513.

16. Senior, R. M., W. F. Skogen, G. L. Griffin, and G. D. Wilner. 1986. Effects of fibrinogen derivatives upon the inflammatory response. Studies with human fibrinopeptide B. J. Clin. Invest. 77:1014-1019.

17. Colman, R. W., and V. J. Marder. 1982. Disseminated intravascular coagulation (DIC): pathogenesis, pathophysiology, and laboratory abnormalities. In Hemostasis and Thrombosis: Basic Principles and Clinical Practice. R. W. Colman, J. Hirsh, V. J. Marden, and E. W. Salzman, editors. J. B. Lippincott Co., Philadelphia. 654-663.

18. Marguerie, G. A., N. Ardaillou, G. Cherel, and E. F. Plow. 1982. The binding of fibrinogen to its platelet receptor. J. Biol. Chem. 257:11872-11875.

19. Thorsen, L. I., F. Brosstad, G. Gogstad, K. Sletten, and N. O. Solven. 1986. Competitions between fibrinogen with its degradation products for interactions with the platelet-fibrinogen receptor. Thromb. Res. 44:611-623.

20. Collen, D., B. Kudryk, B. Hessel, and B. Blomback. 1975. Primary structure of human fibrinogen and fibrin: isolation and partial characterization of chains of fragment D. J. Biol. Chem. 250:58085817.

21. Marder, V. J., H. L. James, and S. Sherry. 1969. The purification of fibrinogen degradation products by Pevikon block electrophoresis. Thromb. Diath. Haemorrh. 22:234-239.

22. Francis, C. W., R. E. Markham, G. H. Barlow, T. M. Florack, D. M. Dobrzynski, and V. J. Marder. 1982. Thrombin activity of fibrin thrombi and soluble plasmic derivatives. J. Lab. Clin. Med. 102:220230 .

23. Lowry, O. H., N. J. Rosebrough, A. L. Farr, and R. J. Randall. 1951. Protein measurement with the Folin phenol reagent. J. Biol. Chem. 193:265-275.

24. Boyum, A. 1968. Isolation of mononuclear cells and granulocytes from human blood. Scand. J. Clin. Lab. Invest. 21 (Suppl 97):77-89.

25. Steigbigel, R. T., L. H. Lambert, Jr., and J. S. Remington. 1974. Phagocytic and bactericidal properties of normal human monocytes. $J$. Clin. Invest. 53:131-142.

26. Mandell, G. L. 1975. Catalase, superoxide dismutase, and virulence of Staphylococcus aureus. J. Clin. Invest. 55:561-566.

27. Kossack, R. E., R. L. Guerrant, P. Densen, J. Schadelin, and G. L. Mandell. 1981. Diminished neutrophil oxidative metabolism after phagocytosis of virulent Salmonella. Infect. Immun. 31:674-678.

28. Babior, B. M., R. S. Kipnes, and J. T. Curnutte. 1973. Biological defense mechanisms. The production by leukocytes of superoxide, a potential bactericidal agent. J. Clin. Invest. 52:741-744.

29. Bass, D. A., T. A. Gonowa, P. Szejda, J. S. Cousant, L. R. Dechatelet, and C. E. McCall. 1980. Eosinopenia of acute infection. Production of eosinopenia by chemotactic factor of acute inflammation. J. Clin. Invest. 65:1265-1271.

30. Hohn, D. C., and R. I. Lehrer. 1975. NADPH oxidase defi- ciency in X-linked chronic granulomatous disease. J. Clin. Invest. 55:707-713.

31. Rosen, H., and S. J. Klebanoff. 1979. Bactericidal activity of a superoxide anion-generating system. A model for the polymorphonuclear leukocyte. J. Exp. Med. 149:27-39.

32. Nelson, R. D., P. G. Quie, and R. L. Simmons. 1975. Chemotaxis under agarose: a new and simple method for measuring chemotaxis and spontaneous migration of human polymorphonuclear leukocytes and monocytes. J. Immunol. 115:1650-1656.

33. Fletcher, M., and J. I. Gallin. 1980. Degranulating stimuli increase the availability of receptors on human neutrophils for the chemoattractant f-met-leu-phe. J. Immunol. 124:1585-1588.

34. Marasco, W. A., J. C. Fancone, R. J. Freer, and P. A. Ward. 1983. Characterization of the rat neutrophil formyl peptide receptor. Am. J. Pathol. 111:273-281.

35. Marasco, W. A., K. M. Becker, D. E. Feltner, C. S. Brown, P. A. Ward, and R. Nairn. 1985. Covalent affinity labeling, detergent solubilization, and fluid-phase characterization of the rabbit neutrophil formyl peptide chemotaxis receptor. Biochemistry. 24:2227-2236.

36. Marasco, W. A., D. E. Feltner, and P. A. Ward. 1985. Formyl peptide chemotaxis receptors on the rat neutrophil: experimental evidence for negative cooperativity. J. Cell. Biochem. 27:359-375.

37. Fischel, S. V., and F. Medzihradsky. 1981. Scatchard analysis of opiate receptor binding. Mol. Pharmacol. 20:269-279.

38. Lehrer, R. I., and L. Cohen. 1981. Receptor mediated regulation of superoxide production in human neutrophils stimulated with phorbol myristate acetate. J. Clin. Invest. 68:1314-1320.

39. TerBush, D. R., and R. W. Holz. 1986. Effects of phorbol esters, diglyceride, and cholinergic agonists on the subcellular distribution of protein kinase $\mathrm{C}$ in intact or digitonin-permeabilized adrenal chromaffin cells. J. Biol. Chem. 261:17099-17106.

40. Gerard, C., L. C. McPhail, A. Marfat, N. P. Stimler-Gerard, D. A. Bass, and C. E. McCall. 1986. Role of protein kinases in stimulation of human polymorphonuclear leukocyte oxidative metabolism by various agonists. Differential effects of a novel protein kinase inhibitor. J. Clin. Invest. 77:61-65.

41. Tauber, A. I. 1987. Protein kinase $C$ and the activation of the human neutrophil NADPH-oxidase. Blood. 69:711-720.

42. Cohen, H. J., M. E. Chovaniec, K. Takashi, and J. C. Whitin. 1986. Activation of human granulocytes by arachidonic acid. Its use and limitations for investigating granulocyte functions. Blood. 67:1103-1109.

43. Saldeen, K., N. Christie, W. R. Nelson, and H. Z. Movat. 1985. Effect of a fibrinogen-derived vasoactive peptide on polymorphonuclear leukocyte emigration. Thromb. Res. 37:85-89.

44. Sueishi, K., S. Nanno, and K. Tanaka. 1981. Permeability enhancing and chemotactic activities of lower molecular weight degradation products of human fibrinogen. Thromb. Haemostasis. 45:9094.

45. Bick, R. L. 1982. The clinical significance of fibrinogen degradation products. Semin. Thromb. Hemostasis. 8:302-330.

46. Gaffney, P. J. 1983. The occurrence and clinical relevance of fibrin fragments in blood. Ann. NY Acad. Sci. 408:407-423.

47. Haynes, J. B., T. M. Hyers, P. C. Giclas, J. J. Franks, and T. L. Petty. 1980. Elevated fibrin(ogen) degradation products in the adult respiratory distress syndrome. Am. Rev. Respir. Dis. 122:841-847.

48. Korchak, H. M., C. Wilkenfeld, A. M. Rich, A. R. Radin, K. Vienne, and L. E. Rutherford. 1984. Stimulus response coupling in the human neutrophil: differential requirements for receptor occupancy in neutrophil responses to a chemoattractant. J. Biol. Chem. 259:74397445.

49. Sklar, L. A., P. A. Hyslop, Z. G. Oades, G. M. Omann, A. J. Jesaitas, R. G. Painter, and C. G. Cochrane. 1985. Signal transduction and ligand-receptor dynamics in the human neutrophil: transient responses and occupancy-response relations at the formyl peptide receptor. J. Biol. Chem. 260:11461-11467.

50. Aviram, I., E. R. Simons, and B. R. Babior. 1984. Reversible 
blockade of the respiratory burst in human neutrophils by a cleavable cross-linking agent. J. Biol. Chem. 259:306-311.

51. Wolfson, M., L. C. McPhail, V. N. Nasrallah, and R. Synderman. 1985. Phorbol myristate acetate mediates redistribution of protein kinase $\mathrm{C}$ in human neutrophils: potential role in the activation of the respiratory burst enzyme. J. Immunol. 135:2057-2062.

52. Tauber, A. I., D. B. Brettler, E. A. Kennington, and P. M. Blumberg. 1982. Relation of human neutrophil phorbol ester receptor occupancy and NADPH-oxidase activity. Blood. 60:333-339.

53. Curnutte, J. T., J. A. Badwey, J. M. Robinson, M. J. Karnovsky, and M. L. Karnovsky. 1984. Studies on the mechanism of superoxide release from human neutrophils stimulated with arachidonate. J. Biol. Chem. 259:11851-11857.

54. Badwey, J. A., J. T. Curnutte, J. M. Robinson, C. B. Berde, M. J. Karnovsky, and M. L. Karnovsky. 1984. Effects of free fatty acids on release of superoxide and on change of shape by human neutrophils: reversibility by albumin. J. Biol. Chem. 259:7870-7877.

55. McPhail, L. C., C. C. Clayton, and R. Synderman. 1984. A potential second messenger role for unsaturated fatty acids: activation of $\mathrm{Ca}^{+2}$-dependent protein kinase. Science (Wash. DC). 224:662-665.

56. Murakami, K., and A. Routtenberg. 1985. Direct activation of purified protein kinase $\mathrm{C}$ by unsaturated fatty acids (oleate and arachidonate) in the absence of phospholipids and $\mathrm{Ca}^{2+}$. FEBS (Fed. Eur. Biochem. Soc.) Lett. 192:189-193.

57. McPhail, L. C., P. S. Shirley, C. C. Clayton, and R. Snyderman. 1985. Activation of the respiratory burst enzyme from human neutrophils in a cell-free system. Evidence for a soluble cofactor. J. Clin. Invest. 75:1735-1739.
58. Curnutte, J. T. 1985. Activation of human neutrophil nicotinamjde adenine dinucleotide phosphate, reduced (triphosphopyridine nucleotide, reduced) oxidase by arachidonic acid in a cell-free system. J. Clin. Invest. 75:1740-1743.

59. Plow, E. F., J. C. Loftus, E. G. Levin, D. S. Fair, D. Dixon, J. Forsyth, and M. H. Ginsberg. 1986. Immunologic relationship between platelet membrane glycoprotein GPIIb/IIIa and cell surface molecules expressed by a variety of cells. Proc. Natl. Acad. Sci. USA. 83:6002-6006.

60. Gustafson, E. J., H. Lukasiewicz, A. H. Schmaier, S. Niewiarowski, and R. W. Colman. 1987. Fibrinogen binds to human neutrophils at a site distinct from GP IIb/IIIa. Clin. Res. 35:598A. (Abstr.)

61. Gramse, M., C. Bingenheimer, W. Schmidt, R. Egbring, and K. Havemann. 1978. Degradation products of fibrinogen by elastase-like neutral protease from human granulocytes. J. Clin. Invest. 78:10271033.

62. Plow, E. F., and T. S. Edgington. 1975. An alternative pathway for fibrinolysis. I. The cleavage of fibrinogen by leukocyte proteases at physiologic pH. J. Clin. Invest. 56:30-38.

63. Doolittle, R. F., K. W. K. Watt, B. A. Cottrell, D. O. Strong, and M. Riley. 1979. The amino acid sequence of the alpha-chain of human fibrinogen. Nature (Lond.). 280:464-468.

64. Wachtfogel, Y. T., W. Abrams, U. Kucich, G. Weinbaum, M. Schapira, and R. W. Colman. 1988. Fibronectin degradation products containing the cytoadhesive tetrapeptide stimulate neutrophil degranulation. J. Clin. Invest. 81:1310-1316. 